JARES, Vol. 4 No. 2 September, 2019; p-ISSN: 2502-826X; e-ISSN: 2503-1163

Copyrights@ Balitar IslamicUniversity, Blitar,Indonesia;

https://ejournal.unisbablitar.ac.id/index.php/jares

\author{
Citation: Hartami Santi, I. (2019). THE DESIGN OF EXPERT SYSTEM APPLICATION FOR \\ DIAGNOSING AUTISM DISORDERS IN CHILDREN \\ JARES (Journal of Academic Research and Sciences), 4(2), 11-19. \\ https://doi.org/10.35457/jares.v4i2.757
}

\title{
THE DESIGN OF EXPERT SYSTEM APPLICATION FOR DIAGNOSING AUTISM DISORDERS IN CHILDREN
}

\author{
Indyah Hartami Santi \\ Computer Science Study Program \\ Information Technology Faculty, Universitas Islam Balitar \\ e-mail: indyahartamisanti@gmail.com,
}

\begin{abstract}
ABSTRAK
The level of public understanding of autistic disorders and how to handle them that still lacking is the main reason in this study. How to know that a child has an autistic disorder or not is generally done by manual and simple way, it done by filling out a checklist or questionnaire that contains facts, attitudes and behaviors that often appear in children. The checklist is filled by parents who will then be observed again by the therapist to get clear, accurate, and reliable results. The weakness from this method in diagnosing there is an autistic disorder or not is it must involve therapists/experts who are currently still few in number.

The purpose of this study is to make a software namely an expert system application that able to diagnose autistic disorders in children that are tailored to the needs of parents. The results of this study are a series of product design systems for expert systems to diagnose autistic disorders in children including ongoing system flowcharts, computerized system flowcharts, Data Flow Diagrams, application program flowcharts and display of application programs that have been built. The results of designing expert system software applications are expected to be used by therapists in diagnosing children who come to consult.
\end{abstract}

\section{Keywords: Autism, Flowchart, Design, Expert System}

\section{INTRODUCTION}

$T^{\mathrm{s}}$ he phenomenon which is the basis of this research is that in 2011 from UNESCO data, the data was obtained that 35 million people with autism in the world. And an average score of 6 out of 1000 people has autism. Especially in Indonesia there is a ratio of 8 out of 1000 people [1]. Public knowledge about autism is considered still low, this has an impact that autistic people are discriminated against while families of patients have difficulty in getting treatment for helping the patients [2]. Some characteristics of autism behavior in children can be seen from language in communication, reactions shown when dealing with other people, concern for the environment, responses shown to the senses/sensory, and attitudes of inequality towards behavior development [3]. While the factors that cause autism are psychological and family factors, socio-cultural factors, and biological factors. Biological factors include genetic factors, pre-natal, additives that pollute the child's brain, neurobiology, and digestive system disorders) [4]. There are many features that can be seen from people with autism, for a prominent feature in Kanner syndrome is empty facial expressions such as being daydreaming, loss of mind and difficult for others to attract attention or invite them to communicate [5]. There are five stages in interpersonal communication to achieve effective communication in children with autism. The five stages are openness, empathy (empathy), 
JARES, Vol. 4 No. 2 September, 2019; p-ISSN: 2502-826X; e-ISSN: 2503-1163

Copyrights@ Balitar Islamic University, Blitar, Indonesia;

https://ejournal.unisbablitar.ac.id/index.php/jares

\section{Citation: Hartami Santi, I. (2019). THE DESIGN OF EXPERT SYSTEM APPLICATION FOR DIAGNOSING AUTISM DISORDERS IN CHILDREN . \\ JARES (Journal of Academic Research and Sciences), 4(2), 11-19. \\ https://doi.org/10.35457/jares.v4i2.757}

support (supportive), positive feelings (positiveness), and equality (equality) [6]. Therapy methods that are carried out for the success of therapy for people with autism can be done by means of behavioral therapy, speech therapy, occu therapy, remediation therapy, play therapy, music therapy, visual therapy, and togetherness therapy. In addition to these therapies, it can also be done by giving special attention, training and education. So that the child is able to develop himself in communicating and interacting with his friends [7]

In various big cities whose people are relatively modern and always keep abreast of the times, the term autistic disorder is well known. On the other hand, in small cities like Blitar, understanding of autistic disorders is still very lacking. One of the institutions specifically dealing with autistic disorders in Blitar is Whising Kids. The process of diagnosing and handling is still done in simple way and uses manual methods. It done by filling out a checklist or questionnaire that contains facts, attitudes and behaviors that often appear in children. The checklist is filled by parents who will then be observed again by the therapist to get clear, accurate, and reliable results. The manual process in diagnosing autistic disorders that always requires experts/therapists causes the system have many shortcomings and weaknesses. So, it needs to have a software application system that can replace the role of expert/therapist in diagnosing autism disorders in patients. This expert system will also be able to provide direction and solutions for parents of patients in handling them.

The purpose of this study is to design and build an expert system to diagnose autistic disorders in children. The design of this expert system is hoped can help parents to know the symptoms of autism early and how to deal with symptoms of autism without having to meet and consult an expert.

\section{RESEARCH METHODS}

This study used research and development methods where the result of the research is an application design that is able to provide alternative solutions and provide facilities for existing systems. In this study, the following steps were taken :

\subsection{Data Collection.}

Data collection is the initial stage in the research method. Where the data used is in the form of primary data and secondary data. Primary data includes symptom data obtained directly from experts and from parents. The experts in question are therapists who are experts in diagnosing autistic disorders. In addition to the common symptoms that are often faced by children, also gather information about the description of the system or procedure that must be done by experts/therapists in the process of diagnosing children who have autistic disorders, until the handling process. Primary data collection is done by conducting interviews and observations of the system that is running at whising kids in the Blitar City. Besides primary data, secondary data is also needed. Secondary data was obtained to supplement the primary data that had been obtained by digging information through reference books and several previous research journals related to autistic disorders

\subsection{Data Analysis and System Needs,}

Primary data and secondary data that have been obtained from the stages of data collection need to be analyzed to get the main problem to be solved. Where the problems faced by parents are difficulty detecting early on autism disorders since early stage. Basic knowledge about autism in the parents is very lacking, especially to recognize symptoms and provide therapy/treatment periodically from early. To be able to find out more about symptoms, signs and therapy in order 
JARES, Vol. 4 No. 2 September, 2019; p-ISSN: 2502-826X; e-ISSN: 2503-1163

Copyrights@ Balitar Islamic University, Blitar, Indonesia;

https://ejournal.unisbablitar.ac.id/index.php/jares

\section{Citation: Hartami Santi, I. (2019). THE DESIGN OF EXPERT SYSTEM APPLICATION FOR DIAGNOSING AUTISM DISORDERS IN CHILDREN . \\ JARES (Journal of Academic Research and Sciences), 4(2), 11-19. https://doi.org/10.35457/jares.v4i2.757}

to be able to take steps and decisions early on dealing with autistic children, there is a need for a system that adapts the knowledge of an expert in autism. Based on the analysis of the problems above, then through this system it is expected to be an alternative choice of consultation, detection, and companion information for parents, where the problem analyzed is about the characteristics of autism and how to handle it.

\subsection{System planning}

The stages of system planning are an important part of the process of building expert system applications. Stages in system planning include:

\section{Make a system flowchart}

The system flowchart in question is the flow of the old system, namely the flow of procedures carried out in whising kids by the therapist on children suspected of having symptoms of autism disorder. Furthermore, from the old system flowchart with deeper analysis, a new system flowchart is created where of the weaknesses and shortcomings and constraints encountered in the old system flowchart to repair the system into a computerized system. In this case the conventional system will be given a solution with an expert system. This expert system will replace the role of experts in diagnosing autism disorders in children so that in the process of diagnosis and consultation do not need to meet and face to face with experts in autism

2. Creating a Data Flow Diagram, this diagram is a diagram that describes the flow of data flowing in a system of software applications. The data flow starts from the beginning of filling in the child's data by inputting the symptoms encountered, and from this data it will be processed so that it will produce a result of the type of autism disorder category. From the type of autism produced by the application system, it will provide the right alternative treatment solution.

3. Make a Flowchart program and display expert system software. This expert system program flowchart is designed to formulate the right programming so that the flow of expert system outputs is produced in accordance with the design and results of previous and expected analysis in accordance with the user needs

\section{RESULTS AND DISCUSSION}

\subsection{The running system}

The running system flowchart is the flow of the system where the patient comes to the registration counter by bringing complete patient data identity. Then the registration counter section records the patient data. Based on the patient data base, the patient meets with an expert/therapist to conduct a consultation. On the basis of the consultation the experttherapist diagnoses the patient whether the symptoms resulting from the consultation process indicate the patient has an autistic disorder or not. The flowchart of the current system flowchart can be illustrated in Figure 1 
JARES, Vol. 4 No. 2 September, 2019; p-ISSN: 2502-826X; e-ISSN: 2503-1163

Copyrights@ Balitar Islamic University, Blitar,Indonesia;

https://ejournal.unisbablitar.ac.id/index.php/jares

\section{Citation: Hartami Santi, I. (2019). THE DESIGN OF EXPERT SYSTEM APPLICATION FOR \\ DIAGNOSING AUTISM DISORDERS IN CHILDREN .}

JARES (Journal of Academic Research and Sciences), 4(2), 11-19.

https://doi.org/10.35457/jares.v4i2.757

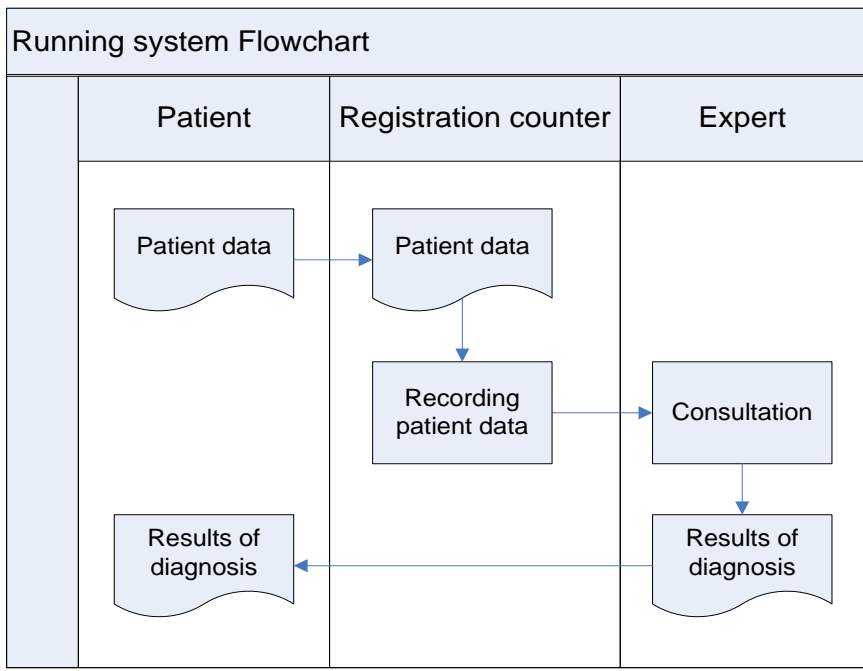

Figure 1. Running System Flowchart

\subsection{Proposed System}

The proposed system flowchart is an advanced stage of the system flowchart that is running. Analysis of the proposed diagnosis (new system). This analysis is made with the aim to facilitate performance in diagnosing a disorder that may be experienced by autistic children. The following is a new system flowchart for expert systems as shown in Figure 2.

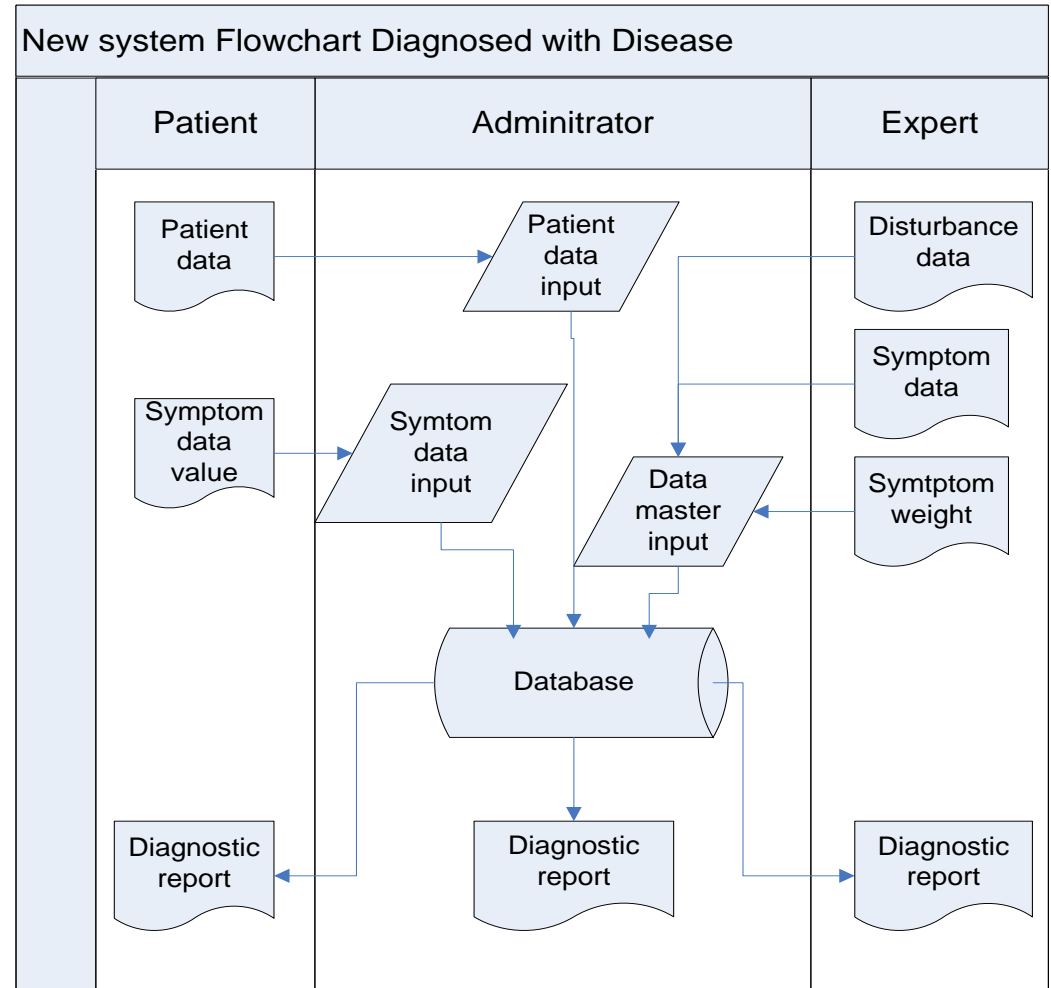

Figure 2. New System Flowchart Diagnosed with Disease

Figure 2 describes the system flow with the user administrator level. In this flow, the process of diagnosing the disorder experienced by the patient will be explained with the help of an 
JARES, Vol. 4 No. 2 September, 2019; p-ISSN: 2502-826X; e-ISSN: 2503-1163

Copyrights@ Balitar Islamic University, Blitar, Indonesia;

https://ejournal.unisbablitar.ac.id/index.php/jares

\section{Citation: Hartami Santi, I. (2019). THE DESIGN OF EXPERT SYSTEM APPLICATION FOR DIAGNOSING AUTISM DISORDERS IN CHILDREN .

administrator. First the user must $\log$ in by entering a username, password, user level (administrator). Then it will enter the main diagnosis menu. In the main diagnosis menu there is a diagnostic option menu, a list of patients and looking for patients. On the patient list menu the user must first enter the patient's biodata to make the diagnosis process. Then the user answers all the symptoms that are felt by the patient. After that the program will do a diagnostic process to save. On the diagnosis menu, the user can see and search for diagnoses that have been done before. Logout menu to exit the system and return to the main login menu. System flow with administrator level is complete.

\subsection{Data Flow Diagram}

\section{DAD level 0}

Zero level DAD is a data diagram that shows the flow of data in general by patient and expert admins. This DAD level comes from Figure 2, with the data flow in the expert system can be seen as shown in the following figure $3:$ :

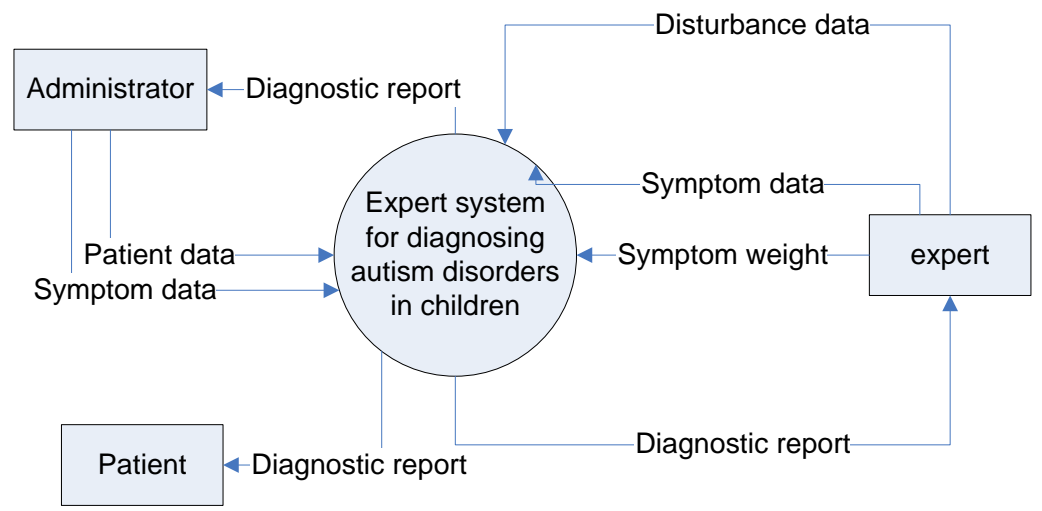

Figure 3. DFD Level 0

\section{DAD level 1}

DAD level 1 is a data flow diagram that refers to the flow of the previous level in figure 3 . This diagram is a more detailed description of the application process of expert systems of autism disorders in children, where in this picture breaks down the process into several processes including process data disruption, process data symptoms, the weighting process, the process of patient data and the process of diagnosis. DAD level 1 is shown as in Figure 4. 
JARES, Vol. 4 No. 2 September, 2019; p-ISSN: 2502-826X; e-ISSN: 2503-1163

Copyrights@ Balitar Islamic University, Blitar, Indonesia;

https://ejournal.unisbablitar.ac.id/index.php/jares

\section{Citation: Hartami Santi, I. (2019). THE DESIGN OF EXPERT SYSTEM APPLICATION FOR \\ DIAGNOSING AUTISM DISORDERS IN CHILDREN . \\ JARES (Journal of Academic Research and Sciences), 4(2), 11-19. \\ https://doi.org/10.35457/jares.v4i2.757}

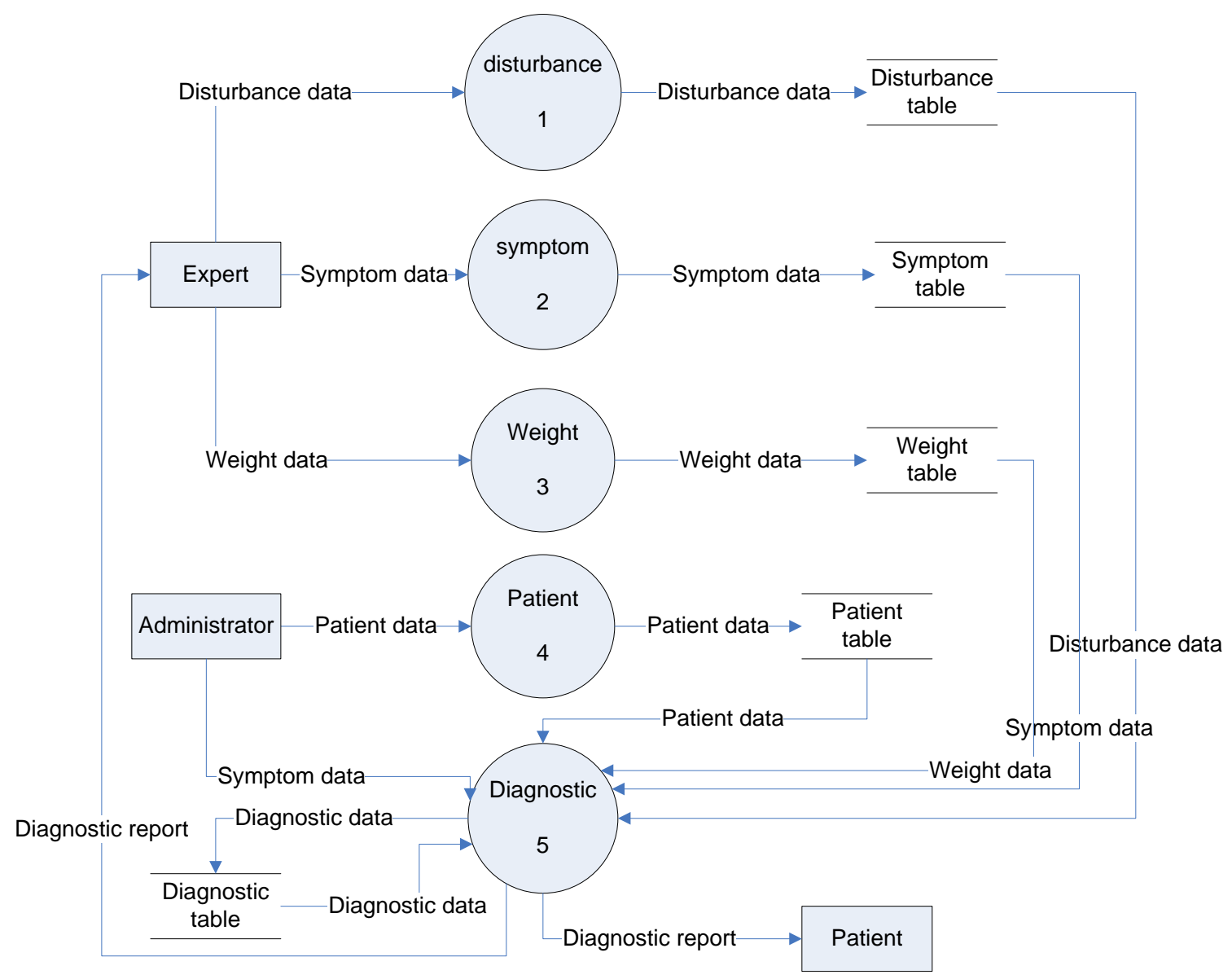

Figure 4. DAD level 1

\subsection{Flowchart programs diagnose autistic disorders}

Flowchart of autistic disorder diagnosis refers to the Data Flow Diagram in Figures 3 and 4, where the program flowchart is more detailed and detailed which better describes the flow of the application program. The application program starts with the user entering the login input. If the login is incorrect, the program will ask the user to log in again until it is correct. If the login entered is appropriate, the process will continue in the diagnosis process. The appearance of the diagnostic process begins with the display of menu options, where the user is asked to make a choice whether to consult or not. If the user does not want to consult the application will return to the menu. Whereas if you choose to do a consultation, the application program will display the data contents of the child, and then the diagnosis process will display the choice of data on the symptoms that appear in the child. From the symptom entry data, the application system performs the process of determining the type of autism disorder category in children which are displayed on the monitor. The flow of the expert system application program flowchart can be seen in figure 5 below: 
JARES, Vol. 4 No. 2 September, 2019; p-ISSN: 2502-826X; e-ISSN: 2503-1163

Copyrights@ Balitar Islamic University, Blitar, Indonesia;

https://ejournal.unisbablitar.ac.id/index.php/jares

\section{Citation: Hartami Santi, I. (2019). THE DESIGN OF EXPERT SYSTEM APPLICATION FOR \\ DIAGNOSING AUTISM DISORDERS IN CHILDREN .}

JARES (Journal of Academic Research and Sciences), 4(2), 11-19.

https://doi.org/10.35457/jares.v4i2.757

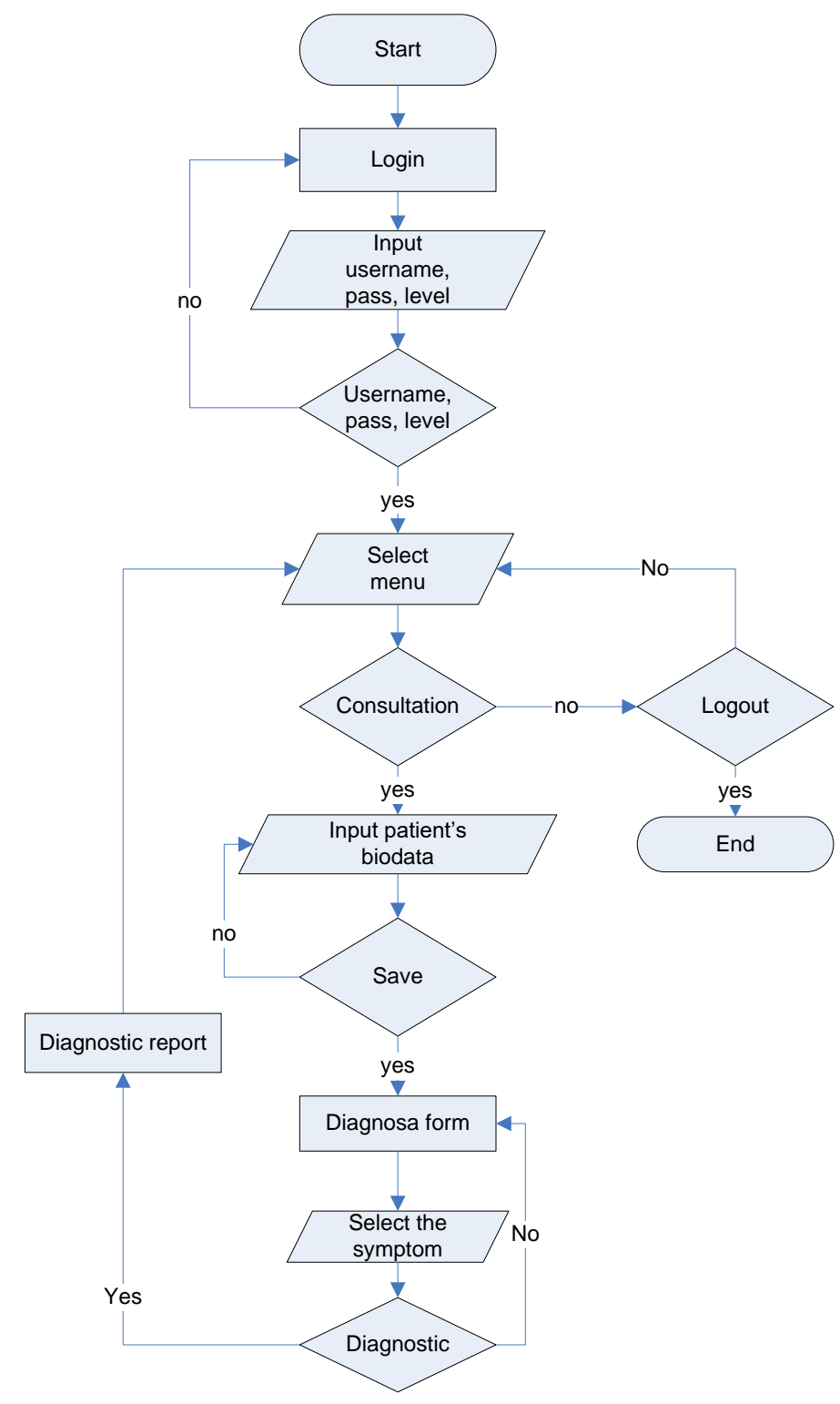

Figure 5. Flowchart of diagnosis

\subsection{The display of Expert System Applications}

1. The initial display of the Expert System application is shown in the following:

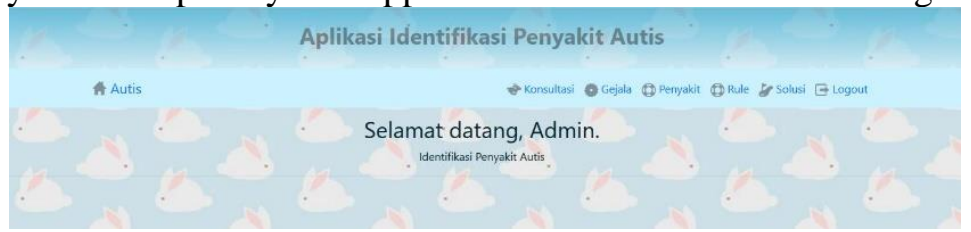

Figure 6. The initial display of the Expert System application

2. The Display of application of symptoms autism disorders and types of autistic disorders in children, can be shown as in Figure 7 and Figure 8. Figure 7 is a list of 35 symptoms of autistic 
JARES, Vol. 4 No. 2 September, 2019; p-ISSN: 2502-826X; e-ISSN: 2503-1163

Copyrights@ Balitar Islamic University, Blitar, Indonesia;

https://ejournal.unisbablitar.ac.id/index.php/jares

\section{Citation: Hartami Santi, I. (2019). THE DESIGN OF EXPERT SYSTEM APPLICATION FOR DIAGNOSING AUTISM DISORDERS IN CHILDREN \\ JARES (Journal of Academic Research and Sciences), 4(2), 11-19. \\ https://doi.org/10.35457/jares.v4i2.757}

disorders that may appear in a child. By selecting each symptom, the system will process and categorize according to the choices available, so the application program will produce a type of autism disorder according to symptom input. Figure 8 is the result of expert system software that classifies autistic disorders according to the symptoms in Figure 7.

\begin{tabular}{|c|c|c|c|c|}
\hline \multicolumn{5}{|c|}{ (9) Tambah Gejala } \\
\hline \multirow{2}{*}{$\begin{array}{c}\text { No } \\
1\end{array}$} & \multirow{2}{*}{\begin{tabular}{|l|} 
Kode \\
G001
\end{tabular}} & \multirow{2}{*}{ Tidak mau tersenyum bila diajak tersenyum } & \multicolumn{2}{|c|}{ Aksi } \\
\hline & & & $\llbracket$ Edit & (3) Hapus \\
\hline 2 & G002 & Tidak bereaksi ketika namanya dipanggil & ¿ Edit & (2) Hapus \\
\hline 3 & G003 & Kecenderungan sangat terpaku dengan benda tertentu & C Edit & (2) Hapus \\
\hline 4 & G004 & Interaksi sosial yang kurang & $\varangle$ Edit & (3) Hapus \\
\hline 5 & G005 & Ekspresi muka yang kurang hidup & $\checkmark$ Edit & (2) Hapus \\
\hline 6 & G006 & Bahasa umum kurang & Edit & (3) Hapus \\
\hline 7 & G007 & Menerima pendekatan sosial & $\checkmark$ Edit & (3) Hapus \\
\hline 8 & G008 & Menarik diri dari lingkungan & $\checkmark$ Edit & (2) Hapus \\
\hline 9 & G009 & la lebih suka bermain sendiri (soliter), meskipun ada teman disisinya & $\varangle$ Edit & (2) Hapus \\
\hline 10 & G010 & Memiliki kecenderungan pendiam dan reflektif & 匹 Edit & (2) Hapus \\
\hline 11 & G011 & Acuh tak acuh & ¿ Edit & (2) Hapus \\
\hline 12 & G012 & Kesal bila didekati & Edit & (3) Hapus \\
\hline 13 & G013 & Memiliki perilaku dan perhatian berlebihan terhadap sesuatu & $\square$ Edit & (8) Hapus \\
\hline 14 & G014 & Lebih banyak menghabiskan waktunya sendiri daripada dengan orang lain & ¿ Edit & (2) Hapus \\
\hline 15 & G015 & Tidak tertarik untuk berteman & Edit & (2) Hapus \\
\hline 16 & G016 & Tidak bereaksi terhadap isyarat & $\varangle$ Edit & (8) Hapus \\
\hline 17 & G017 & Mau bermain dengan anak yang lain & उ Edit & (3) Hapus \\
\hline 18 & G018 & Mau bermain jika pola mainnya sesuai dengan dirinya & $\square$ Edit & (9) Hapus \\
\hline 19 & G019 & Bayi tampak terlalu tenang (jarang menangis) & $\varangle$ Edit & (8) Hapus \\
\hline 20 & G020 & Terlalu sensitif, cepat terganggu/terusik & $\varangle$ Edit & (8) Hapus \\
\hline 21 & G021 & Anak terlihat lamban & $\square$ Edit & (2) Hapus \\
\hline 22 & G022 & Kurang gesit & ๔ Edit & (2) Hapus \\
\hline 23 & G023 & Kurang suka kegiatan fisik & $\square$ Edit & (2) Hapus \\
\hline 24 & G024 & Cepat mengaku lelah & $\square$ Edit & (8) Hapus \\
\hline 25 & G025 & Secara spontan akan mendekati anak lain & $\square$ Edit & (6) Hapus \\
\hline 26 & G026 & Anak sukar duduk diam & $\square$ Edit & (2) Hapus \\
\hline 27 & G027 & Selalu tergesa-gesa dalam mengerjakan sesuatu & $\square$ Edit & (3) Hapus \\
\hline 28 & G028 & Lebih sering menggerakkan kaki dan tangannya & $\square$ Edit & (2) Hapus \\
\hline 29 & G029 & Menunjukkan pola perilaku yang selalu berlebihan & $\square$ Edit & (3) Hapus \\
\hline 30 & 6030 & Sering berlari dan memanjat & $\varangle$ Edit & 6 Hapus \\
\hline 31 & G031 & Tingkah lakunya tidak mempunyai tujuan yang jelas & Edit & (2) Hapus \\
\hline 32 & G032 & Mengalami kesulitan konsentrasi & Edit & (8) Hapus \\
\hline 33 & G033 & Cenderung menentang & $\square$ Edit & (2) Hapus \\
\hline 34 & G034 & Cenderung cepat bosan & Edit & (2) Hapus \\
\hline 35 & G035 & Anak seakan tak kenal lelah & $\square$ Edit & (2) Hapus \\
\hline
\end{tabular}

Figure 7. Appearance of symptoms of autism disorders 
JARES, Vol. 4 No. 2 September, 2019; p-ISSN: 2502-826X; e-ISSN: 2503-1163

Copyrights@ Balitar Islamic University, Blitar, Indonesia;

https://ejournal.unisbablitar.ac.id/index.php/jares

\section{Citation: Hartami Santi, I. (2019). THE DESIGN OF EXPERT SYSTEM APPLICATION FOR DIAGNOSING AUTISM DISORDERS IN CHILDREN . \\ JARES (Journal of Academic Research and Sciences), 4(2), 11-19. https://doi.org/10.35457/jares.v4i2.757}

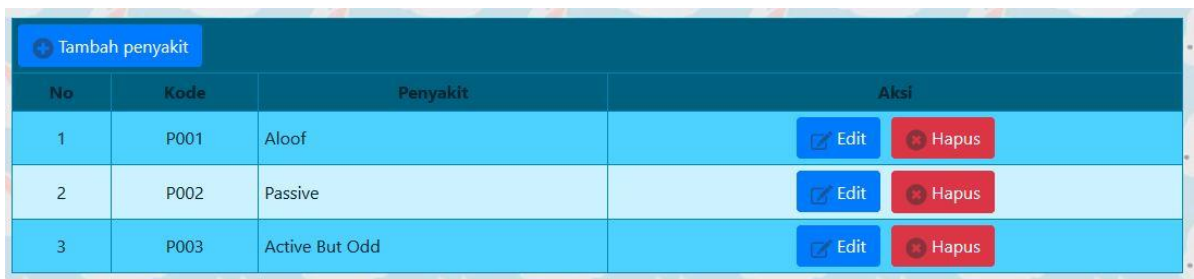

Figure 8. Types of autistic disorders categories

\section{CONCLUSION}

Based on the problems faced by whising kids in the process of diagnosing autism disorders in children, the research process began with data collection and analysis the system requirements, so the results of this study were the resulting design of software applications that can diagnose autistic disorders. The design started from the design of the old system Flowchart and computerized system Flowchart, the design of DAD level 0 and DAD level 1 and the Flowchart Application program along with the application display diagnoses autism disorder. From this design, a software application that has built was expected to help parents and therapists diagnose autism in children.

\section{SUGGESTION}

This study resulted in the design of an expert system application of autism disorders in children that have not been tested to parents who have children with symptoms of autistic disorders, so it is recommended to continue and develop this expert system design to make it more useful.

\section{THANK-YOU NOTE}

The author would like to thank the Chancellor and Elementary officials below him at Balitar Islamic University who have provided material and non material support so that this research can be carried out as expected.

\section{BIBLIOGRAPHY}

[1] Danuatmaja, Doni.2003. Terapi Anak Autis Dirumah. Jakarta : IISIP.

[2] Purnomo, PM, 2015, Penerimaan orang tua terhadap anak penderita Autis di Surakarta, Fakultas Psikologi Universitas Muhammadyah Surakarta

[3] Handojo. 2004. Autisme : Petunjuk Praktis \& Pedoman Materi untuk Mengajar Anak Normal, Autis dan Perilaku Lain. Jakarta: Bhuana Ilmu Populer

[4] Suryana, A. (2004). Terapi autisme, anak berbakat dan anak hiperaktif. Jakarta: Progres Jakarta.

[5] Rohman Fahrur Feri, Fauziyah Ami, 2008, Sistem Pakar Untuk Menentukan Jenis Gangguan Perkembangan Pada Anak. Media Informatika

[6] Sembiring, CE, 2014, Komunikasi Antarpribadi Pada Anak Penderita Autisme, Fakultas Ilmu Sosial dan Ilmu Politik Unibersitas Sumatra Utara

[7] Suteja, 2014, Bentuk dan Metode Terasi Terhadap Aak Autis Akibat bentukan perilaku sosial, Jurnal Edueksos Vol III No 1, January-June 2014 